\title{
Dripping test to assessment the water content in frozen chicken carcases commercialized in Ji-Paraná, Rondônia, Brazil
}

\section{Dripping test para avaliação do teor de água em carcaças de frango congeladas comercializadas em Ji-Paraná, Rondônia, Brasil}

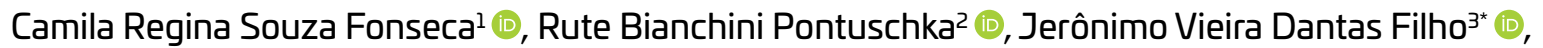 \\ Ademilson de Assis Dias ${ }^{4}$ (1), Bruna Laurindo Rosa4 (1), Paulo Henrique Gilio Gasparotto ${ }^{1,4}$ (1)
}

\begin{abstract}
The growth in demand for chicken meat is due to the increase in demand for white meat, as they are considered tasty and at an attractive price. Therefore, the search for quality is essential. In Brazil, the water loss due to the melting of the carcasses is controlled by companies and by the Ministry of Agriculture, Livestock and Supply (MAPA) and, frequently, they analyze water loss from the carcasses above the limits required by the legislation. Given the assumption, the aimed of this study was to evaluate the water losses due to thawing in frozen chicken carcasses marketed in the municipality of JiParaná, Rondônia, Brazil. There 25 carcasses of whole frozen chickens were evaluated, from six brands, lots and different establishments, submitted to standardized conditions for the performance of the Dripping test, in order to verify the percentage of water absorbed by the carcasses. It was found that $48 \%$ of the samples showed water loss beyond that allowed by the current legislation, which is $6 \%$. When observing that almost half of the evaluated carcasses showed irregularities in relation to the legislation, it is understood that the companies that supply these products should be better inspected, carrying out Dripping test analyzes periodically to reduce or eliminate this type of crime.
\end{abstract}

KEYWORDS: Fraud; Frozen chicken; Drip test; Thawing.

RESUMO: O crescimento da demanda de carne de frango se deve ao aumento da procura de carnes brancas, por serem consideradas saborosas e com preço atrativo. Por isso, a busca pela qualidade é imprescindível. No Brasil, a perda de água pelo degelo das carcaças é controlada pelas empresas e pelo Ministério da Agricultura Pecuária e Abastecimento (MAPA) e, frequentemente, analisam perda de água das carcaças acima dos limites exigidos pela legislação. Diante do pressuposto, o objetivo desse estudo foi avaliar as perdas de água por degelo em carcaças de frango congeladas comercializadas no município de Ji-Paraná, Rondônia. Foram avaliadas 25 carcaças de frangos congelados inteiros, de seis marcas, lotes e estabelecimentos distintos, submetidos a condiçōes padronizadas para a realização do Dripping test, com a finalidade de verificar o percentual de água absorvida pelas carcaças. Constatou-se que $48 \%$ das amostras apresentaram perda de água além do permitido pela legislação vigente, que é de $6 \%$. Ao observar que quase a metade das carcaças avaliadas apresentaram irregularidades frente à legislação, entende-se que as empresas fornecedoras desses produtos devem ser melhor fiscalizadas, realizando análises de Dripping test periodicamente para reduzir ou eliminar esse tipo de delito.

PALAVRAS-CHAVE: Descongelamento; Frango congelado; Fraude; Teste de gotejamento.

\section{INTRODUCTION}

The growth in demand for chicken meat is due to the increased demand for white meat, as they are considered tasty, healthy and with an attractive price (NOVELLO et al., 2008; POTENÇA et al., 2010). However, for chicken production in Brazil to continue meeting national and global demands, the processing of carcasses concerning hygienic-sanitary and economic aspects are very important factors to be considered (MANCINELLI et al., 2018), especially regarding the content of water retained in the carcasses, because excess water can be an indicator of inferior meat excess retention will result in the production of inferior meat (SENTANDREU; SENTANDREU, 2014).

\footnotetext{
${ }^{1}$ Curso de Medicina Veterinária, Centro Universitário São Lucas (UNISL), Ji-Paraná, RO, Brasil ¿Curso de Zootecnia, Universidade Federal de Rondônia (UNIR), Presidente Médici, RO, Brasil 3Programa de Pós-Graduação em Ciências Ambientais, Universidade Federal de Rondônia (UNIR), Rolim de Moura, RO, Brasil ${ }^{4}$ Programa de Pós-Graduação em Sanidade e Produção Animal Sustentável na Amazônia Ocidental, Universidade Federal do Acre (UFAC), Rio Branco, AC, Brasil *Corresponding author: jeronimovdantas@gmail.com Received: 16/11/2020. Accepted: 07/01/2021
} 
The stages of pre-cooling and cooling of whole carcasses or cuts, occur through tanks with chilled water, in order to prepare the carcass/cut for freezing and/or cooling and to eliminate the risk of contamination by Salmonella sp., for example. This process occurs during the slaughter stage, because of the blood, feathers and viscera, possibly discarded. If inspected improperly, these steps may lead to an increase in the percentage of water absorption by the carcasses, freezing together with the product, perhaps the draining is not performed properly (SENTANDREU; SETANDREU, 2014).

Thus, in order to carry out the marketing of chicken, the carcass should not contain excess frozen water, as it will be considered as a loss to the consumer, who will pay for a product that does not comply with Ordinance 210 of the Ministry of Agriculture and Livestock and Supply (MAPA) (BRASIL, 1998), which provides for procedures for determining the amount of water in poultry carcasses, characterizing this situation as fraud (BRASIL, 2002; KATO et al., 2013; SENTANDREU; SENTANDREU, 2014). In order for this monitoring to be performed, the Dripping Test analysis, described in MAPA Ordinance No. 210 (BRAZIL, 1998), is applied, which estimates the moisture absorbed by the carcasses during pre-cooling and then thawing. It is worth noting that values above $6 \%$ of water in the frozen carcass are indicators of excess moisture absorption, thus being pointed out as an irregularity according to MAPA Ordinance 210 (BRASIL, 1998).

The possibility of fraud in the chicken carcass with excess water usually occurs when the carcasses are kept for a long time in cooling or also when brines are injected into the meat (KATO et al., 2013). In the market, after the frozen product, it is difficult for the consumer to check the excess water contained in the frozen chicken. However, when defrosting the carcass, it is possible to notice the fraud (KATO et al., 2013). The excess of water in frozen chicken damages the economy, not only to consumers, but also to the production chain (NASS et al., 2019). Due to this problem, some Brazilian enterprises lose the opportunity to export the meat and with that Brazil loses collection opportunities (PAVIM; FRANCE, 2011).

When these carcasses have a percentage of water above that allowed, the offending company suffers penalties applied by the Department of Inspection of Products of Animal Origin (DIPOA), which may be a warning, fine, interdiction of production and collection of these commercialized products. Therefore, it is necessary for the company to prove, through official laboratory analyzes, that the batches produced after the irregular batch are able to be marketed, because, otherwise, they may suffer new seizures of their product in the retail trade or at the place of production (FERNANDES, 2008; PAVIM; FRANCE, 2011). Thus, it was determined that companies develop a Program for the Prevention and Control of Water Addition to Products (PPCAAP), carefully presenting the controls carried out in order to prevent possible occurrences of fraud due to production processes in the derivatives industry (PAVIM; FRANCE, 2011).
There is great concern on the part of consumers about possible changes in the weight of frozen carcasses marketed. Therefore, it was necessary to develop a study with frozen chickens with giblets commercialized in supermarkets in the municipality of Ji-Paraná, RO, Brazil. Given the assumption, the aimed of this study was to evaluate the weight losses due to thawing in frozen chicken carcasses marketed in the municipality of Ji-Paraná, Rondônia, Brazil.

\section{MATERIAL AND METHODS}

\section{Data collect}

The 25 samples of frozen carcasses with five different brands were evaluated. From each brand, five samples were analyzed, each from a different batch. All carcasses were purchased at different supermarkets in the municipality of Ji-Paraná, RO, Brazil. The samples were transported in isothermal boxes at a temperature of $-12^{\circ} \mathrm{C}$ as required by MAPA (Ordinance N. 210) and sent to the Laboratory of Analysis and Technology of Products of Animal Origin at Centro Universitário São Lucas, Campus Ji-Paraná. The carcasses were evaluated using the Dripping test, which quantifies the volume of water lost after thawing the carcass, with the kids (edible parts), so that the thawing is done under controlled conditions, which make it possible to check the water weight lost in defrosting.

\section{Dripping test}

The Dripping Test was performed on 25 carcass samples $(\mathrm{n}=25)$. The values were considered unacceptable in reference to the average water resulting from the thawing of each sample (composed of six carcasses) was greater than 6\% (BRASIL, 1998). For carrying out the test, the steps (Figure 1) described by MAPA Ordinance No. 210/1998 were respected (BRASIL, 1998).

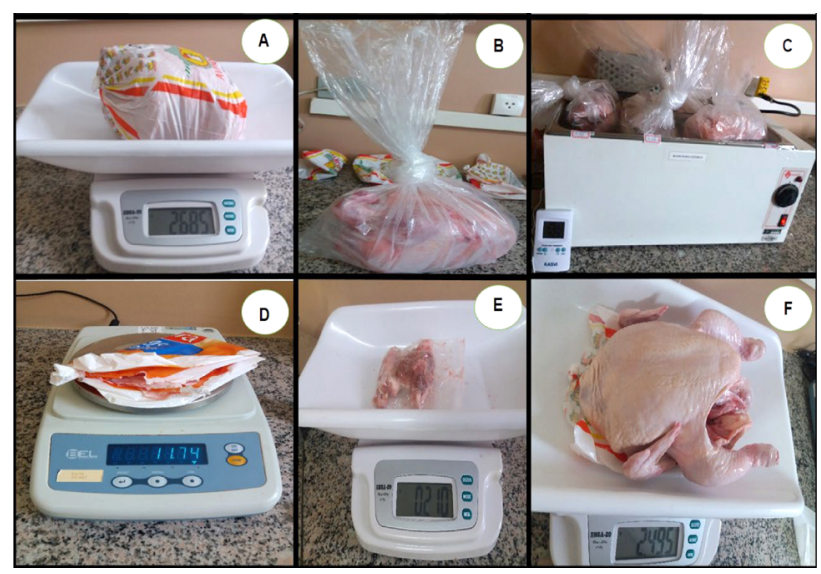

Figure 1. Steps taken during the Dripping test analyzes. (A) Weighing of the frozen carcass, (B) Carcass in a plastic bag, (C) Immersion in a water bath at $42^{\circ} \mathrm{C}$, (D) Weighing of the original packaging, (E) Weighing of the viscera and (F) Weighing of the carcass with offal and original packaging after thawing at $42^{\circ} \mathrm{C}$. 


\section{Statistical analysis}

The proportions of carcasses analyzed by the Dripping test above $6 \%$ were compared with each other using the chi-square test or Fisher's exact test, when applicable. And, considering the significance level of $95 \%(\alpha=0.05)$. The statistical procedures were performed using the R software (R CORE TEAM, 2013).

\section{RESULTS}

The results of the Dripping test in the 25 samples are shown in Table 1.

Table 1. Results of the samples through the Dripping Test of frozen chicken carcasses commercialized in Ji-Paraná, RO, Brazil.

\begin{tabular}{l|c|c|c} 
Brands & $\begin{array}{c}\text { Samples } \\
(n)\end{array}$ & $\begin{array}{c}\text { Samples above } \\
6 \%(n)^{1}\end{array}$ & $\begin{array}{c}\text { Samples below } \\
6 \%(n)^{2}\end{array}$ \\
\hline 1 & 5 & $4 / 5$ & $1 / 5$ \\
\hline 2 & 5 & $3 / 5$ & $2 / 5$ \\
\hline 3 & 5 & $1 / 5$ & $4 / 5$ \\
\hline 4 & 5 & $2 / 5$ & $3 / 5$ \\
\hline 5 & 5 & $2 / 5$ & $3 / 5$ \\
\hline Total & 25 & $12 / 25$ & $13 / 25$ \\
\hline
\end{tabular}

'Above and ${ }^{2}$ below the limit allowed by legislation, Ordinance N. 210 of November 10, 1998 from MAPA (BRASIL, 1998).
It was found that $52 \%(13 / 25)$ of the samples had values within the acceptable limit and 48\% (12/25) of the samples had a percentage of moisture above that allowed by Decree 210/1998 of MAPA (BRASIL, 1998). These results demonstrate a high water content in the carcasses, which may be related to the inability of technical control by the companies during the processing steps, in which case, cooling by immersion in water is one of the most used methods. On the other hand, it is the method in which the greatest water weight gains occur, as well as, possible operational or fraudulent problems.

In Figure 2, it is possible to observe the existence of variations in water content between carcasses of the same brand and between carcasses of different brands, suggesting a heterogeneity in the absorption of water in the carcasses $(p<0.05)$, with the brands presented one or more samples outside the standard required by current legislation.

\section{DISCUSSION}

The article 879 of the Regulation for Industrial and Sanitary Inspection of Products of Animal Origin RIISPOA (BRASIL, 2017) portrays adulteration referring to the preparation of products in disagreement with the established specifications, and portrays fraud as the act in which the product is

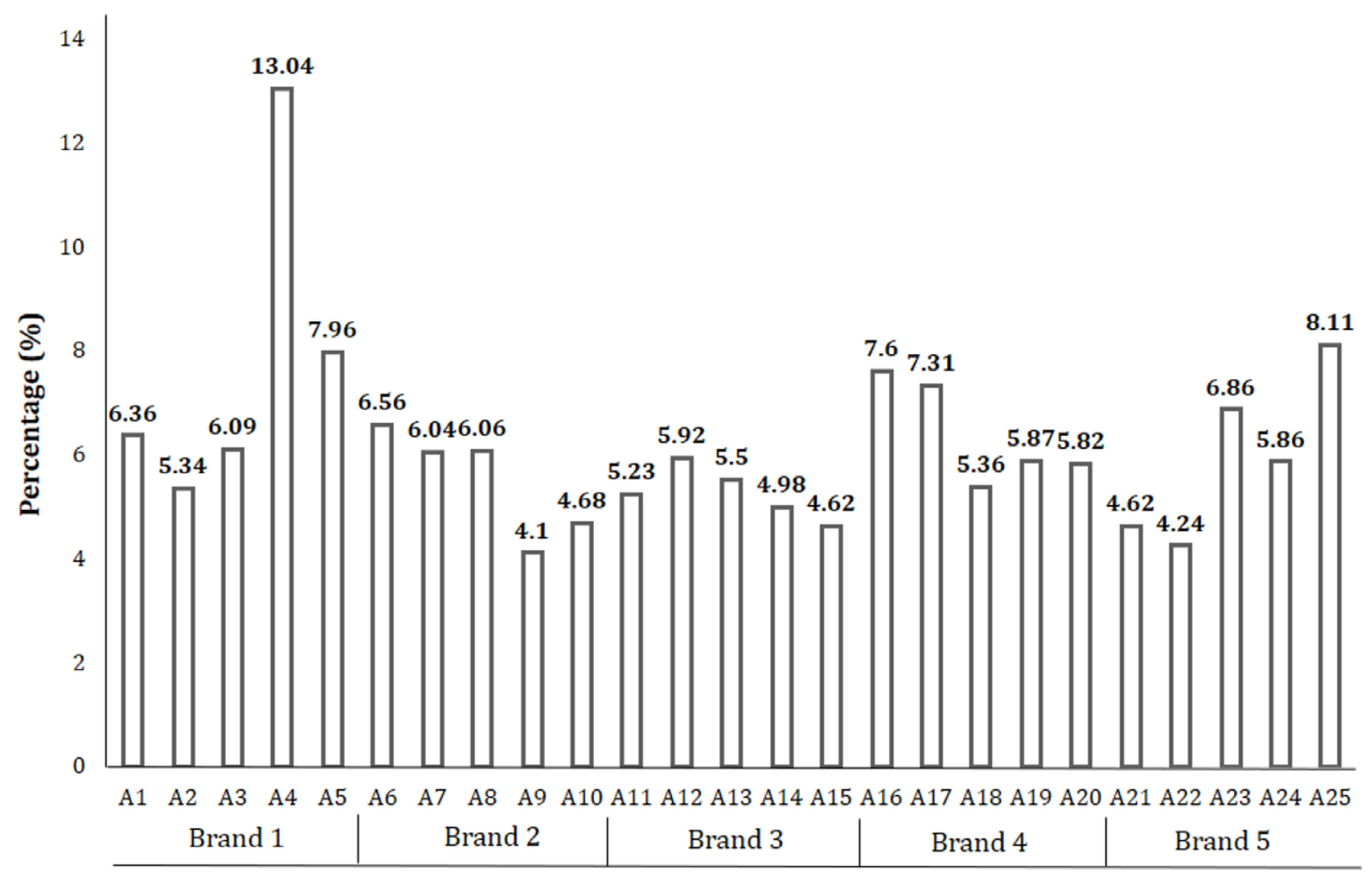

Samples (A1 - A25)

Figure 2. Individual percentage of the samples analyzed by the Dripping test method of frozen chicken carcasses commercialized in Ji-Paraná, RO, Brazil. 
modified or altered one or more components of the product, totally or partially, according to the standards required by DIPOA (FERREIRA, 2010). The results obtained apparently indicate that there was possibly fraud. However, Carciofi (2005) when conducting a study in industries in the state of Santa Catarina, having evaluated several aspects related to the reduction of temperature and water absorption by immersion cooled carcasses. The results indicated that water temperature, hydrostatic pressure, water agitation and immersion time are indicators of the percentage of water absorbed by the carcasses during the immersion cooling process. Thus, the author was able to verify that the carcass cooling step is a complex process, since the carcass cooling in chillers is an intricate process of simultaneous heat and mass transfer, which needs control to guarantee the quality of frozen products.

During the slaughter process, the chickens are subjected to several washes with water. In the pre-cooling phase, the carcasses are immersed in tanks with water at $16^{\circ} \mathrm{C}$ for 30 minutes. At this stage, the greatest absorption occurs due to the incorporation of water by the muscle fibers of the meat. But, the freezing step can also result in excess water. The speed of freezing the meat, slow or fast, determines the proportions of ice crystallization in the carcass. The size and shape of the ice crystals determine the percentage of water released on thawing. To avoid this problem, it is important to correctly drip the product immediately after pre-cooling, in stainless steel equipment, with a drip water collecting trough, suspended and arranged along the conveyor (QUEIROZ, 2015).

The immersion of the carcass in the cold water tank (called a chiller) has the role of decreasing the temperature of the carcasses, aiming at reducing the multiplication of bacteria. However, this step can increase the percentage of water absorbed by the muscle, increasing the weight of the carcass in relation to its original weight (ÇENGEL, 2012; SIMAS et al., 2013; BAILONE; ROÇA, 2017). Another factor that influences the percentage of water is the time that the carcasses remain in the drip line. In this case, the minimum time is $3 \mathrm{~min}$, taking into account that this process aims to avoid excess water absorbed in the pre-cooling and immersion cooling steps. The percentage of water absorbed at the end of the drip does not exceed $6 \%$ of the initial mass (BRASIL, 1998; KATO et al., 2013).

MAFRA (2014) conducted a study in Londrina, in the state of Paraná, on water loss in chicken carcasses by Dripping test with 5 brands of frozen chicken commercialized. In the study, three brands were verified with values beyond what is allowed by the legislation, since the highest average found was $8.32 \%$. The author concluded that there was an excess of water absorption during cooling in the chillers by immersion in water. In the present study, all the brands analyzed showed at least one result above $6 \%$, and the sample that obtained the highest average was $13.04 \%$, surpassing the highest average of the research by Mafra (2014). Similarly, Garnica et al. (2014) demonstrated that out of 84 analyzed samples of businesses and industries in the states of Goiás, Mato Grosso, Mato Grosso do Sul and the Distrito Federal, from November 2000 to September 2001, since $74.57 \%$ (66/80) of the samples expressed values higher than that determined by the legislation, which led to the conclusion that such samples could have been stored under critical conditions of conservation, under freezing, as there was the formation of ice crystals due to the recrystallization of moisture. Thus, these crystals promoted the injury and the rupture of the fibers and membranes of the meat, which allows the lowest moisture when the product was thawed, leading to presenting results above the limit. This research has a great similarity with the values found in the present study with regard to the percentage of water lost in the defrost.

Aguiar (2009), in a study conducted in the state of Minas Gerais, carried out an analysis of 3 brands, of which two presented a percentage above that allowed by the legislation. The samples were acquired in retail stores in the cities of Belo Horizonte, Betim, Contagem, Sete Lagoas and Diamantina, being the most commercialized brands in Minas Gerais state. And, according to the study, the samples that showed a value above the established, because they absorbed an excess of water (above 6\%) during cooling by immersion in water, that is, in the chillers. This result is an indication of the possibility of fraud, which demonstrates how common it is to find results above the limit allowed during the analyzes, even in different cities and lots of frozen birds.

Queiroz et al. 2015, in a study of the percentage of water in frozen chicken carcasses commercialized in supermarkets in the city of Rio Branco, in the state of Acre, from 18 samples it was found that up to $66 \%$ presented values above what is allowed by the legislation. This allowed the authors to conclude that there are frozen chicken carcasses being commercialized in the city of Rio Branco in a fraud situation, and that there is no relationship between the carcass size and the amount of water absorbed in the processing steps. Likewise, Gonçalo et al. 2020, in a study similar to that of Queiroz et al. (2015) in supermarkets in the city of Rio Branco, also in the state of Acre, out of 30 samples, it was found that $50 \%$ presented values above what is allowed by the legislation. The results obtained by these authors indicated that better inspection and control by the responsible bodies and companies is necessary in the stage of cooling the carcasses.

Negrini et al. (2007), in a study similar to this research, evaluated 30 frozen chicken carcasses, corresponding to six samples for each brand and, five different brands, were collected to measure the percentage of water lost after thawing. The results expressed that of the five brands analyzed, three (60\%) presented unsatisfactory percentages, because the averages of the six carcasses showed values above 6\%. The same authors found indexes close to those found by Gomes and 
Azevedo (2009), these authors found 47 samples of frozen chickens, marketed in the city of Rio de Janeiro, in the period from 2004 to 2005 , of which $68 \%$ presented values above the allowed. The results observed by the authors verified the presence of technological flaws in two slaughterhouses in the precooling, which resulted in water absorption beyond the permitted limits, therefore, this practice consists of commercial fraud when the products reach the reach of consumers.

In the research conducted by Brizio (2012), in a slaughterhouse under federal inspection located in the state of Rio Grande do Sul, whose slaughter capacity is 500 thousand animals per day, obtained satisfactory results, demonstrating that the company where the research was carried out has appropriate control of the carcass cooling process, noting that the care taken as the detailed control of temperature and renewal of the water in the tanks, time spent in the chillers, and the maximum temperature observed in the company's pre-chillers was $8^{\circ} \mathrm{C}$, with a residence time of 22 to 28 minutes. The standardization of the size and age of the birds and the rapid freezing of the products, were essential to obtain the results that, in fact, match those obtained by Negrini et al. (2007). In this last work, 150 chickens obtained from two shifts of a refrigeration unit in a period of three months were evaluated. And, it was found that there were no inadequacies, because the average percentage of absorption was $5.27 \%$, below the limit stipulated by current legislation.

In the study conducted by Negrini et al (2007), the process control parameters regulated by MAPA, through Ordinance N. 210/1998, were in compliance during the period evaluated. These results differ significantly from those analyzed in other similar studies, and differ greatly from the results presented in that study in which a significant percentage of the samples were above the established limit, thus emphasizing that the justifications mentioned about failures in temperature control, absorption in excess water during cooling in the chillers, inadequate dripping or non-compliance with the estimated time and among many other factors can be a real problem in changing the weight of the carcass leading to unwanted water absorption (LORENZETTI, 2016).

It should be noted that the quality of the carcass is not affected by excess water, however, the consumer will pay for the water contained in the product. It is noticed that in some states of Brazil (Paraná and the Midwest region) there are still frauds by adding water, some being induced, others not; there are failures in the stage and/or quality control in the industries, such as in the bubbling system, in the cooling system, in the water temperature, in the safety of the product, among others, still happen frequently (NASS et al., 2019). So that this weight change does not occur, it is necessary to monitor, as well as, routine evaluation, with collection of samples for commercialization without prior notice, in order to ensure the interests of consumers and prevent intentional fraud, especially, in establishments that frequently show excess water (LORENZETTI, 2016).

\section{CONCLUSION}

Through the Dripping test analysis, deviations from legal standards were contacted in the percentage of water absorbed in the production process of frozen chickens sold in the municipality of Ji-Paraná, RO, Brazil. Therefore, strict monitoring of the industrial process is crucial, so that, if it can point out possible processing errors. It is worth mentioning that one of the main purposes of inspection is to identify operational or fraudulent problems.

\section{REFERENCES}

ACUIAR, E. F. Avaliação do índice de hidratação e características de qualidade das carcaças de frangos inteiros congelados e 10 temperados produzidos no estado de Minas Gerais. 2009. $54 \mathrm{f}$. Dissertação (Mestrado em Zootecnia) - Universidade Federal dos Vales do Jequitinhonha e Mucuri, Diamantina, 2009.

BAILONE, R. L.; ROÇA, R. O. Tendências no processamento de frangos de corte: uso racional da água. Revista de Engenharia Sanitária e Ambiental, v. 22 n. 1, p. 65-72, 2017.

GARNICA, F. M.; ROSSI, G. A. M.; GONÇALVES, A. C. S.; AGUILAR, C. E. G., ALMEIDA, H. M. S.; MARTINS, A. M. C. V. Avaliação do teor de líquido perdido por degelo de frangos congelados (Dripping test) consumidos no centro-oeste do Brasil. Revista Brasileira de Ciência Veterinária, v. 21, n. 1, p. 64-66, 2014.

BRASIL. Ministério da Agricultura, Pecuária e Abastecimento. DCl/ DIPOA. Portaria n. 210, de 10 de novembro de 1998. Aprova o Regulamento Técnico da Inspeção Tecnológica e Higiênico
Sanitária da Carne de Aves. Diário Oficial da União, Brasília, 26 de novembro de 1998, Seção 1, p. 226.

BRASIL. Ministério da Agricultura, Pecuária e Abastecimento. Departamento Nacional de Inspeção de Produtos de Origem Animal. Regulamento da Inspeção Industrial e Sanitária de Produtos de Origem Animal - RIISPOA. Brasília: MAPA 2017. Disponível em: <http:/www.planalto.gov.br/ccivil_03/_ato2015-2018/2017/ decreto/D9013.htm>Acesso em 27 de mai. de 2020.

BRIZIO, A. P. R.; FAGUNDES, G. A.; PRENTICE, C. Avaliação quantitativa do teor de água contido em cortes congelados de frango. Revista Brasileira de Pesquisa em Alimentos, v. 3, n. 1, p. 69-71, 2012.

CARCIOFI, B. A. M. Estudo do resfriamento de carcaças de frango em chiller de imersão em água. 2005.107 f. Dissertação (Mestrado em Engenharia de Alimentos) - Universidade Federal de Santa Catarina, Florianópolis, 2005. 
ÇENGEL Y. A. Transferência de Calor e Massa: Uma Abordagem Prática. 4. ed.Tradução Lino FAM. São Paulo: McGraw-Hill Interamericana do Brasil Ltda., 2012.

CUNHA, H. V. F. Uso de hormônios em frangos. Revista de Higiene Alimentar, v. 30, п. 256/257, 2016.

FERNANDES, C. M.; PAZ, G. F.; LINS, J. C. Avaliação das condições de frigorificação de carcaças de frangos de corte em diferentes pontos do processo produtivo, distribuição e comercialização. 2008. 45 f. Dissertação (Mestrado em Higiene e Inspeção de Produtos de Origem Animal) - Universidade Castelo Branco, Palmas, 2008.

FERREIRA, V. F. Fluxograma do abate de aves e índice de absorção de água em carcaças de frango. 2010. $68 \mathrm{f}$. Monografia (Graduação em Medicina Veterinária) - Universidade Federal de Goiás, Jataí, 2010.

GOMES, V. L. M.; AZEREDO, D. P. Avaliação do teor de água em frangos congelados comercializados no Rio de Janeiro, pelo método de gotejamento (Drip Test). Revista Higiene Alimentar, v. 23, п. 168/169, p. 138-145, 2009.

GONÇALO, E. N.; MESSIAS, C. T.; QUEIROZ, A. M.; FREITAS, H. J.; ARAÚJO, D. S. S.; QUEIROZ, S. L. O.; SILVA, L. A.; MARCHI, P. G. F. Percentage of water in frozen chicken carcass, sold in supermarkets, Rio Branco, Acre. Brazilian Journal of Development, v. 6, n. 9 , p. 71245-71254, 2020.

KATO, T. et al. Release of meat and water from PSE-cut chicken (Pale, Soft, Exsudative) during the thawing of the chicken carcass and Brazilian legislation. Brazilian Archives of Biology and Technology, v. 56, n. 6, p. 996-1001, 2013.

LORENZETTI, E. Estudo das variáveis que interferem, na absorção de água em carcaças e cortes de frango durante a etapa de préresfriamento. 2016. 126 f. Tese (Doutorado em Engenharia de Alimentos) - Universidade Regional Integrada do Alto Uruguai e das Missões, Erechim, 2016.

MAFRA, M. A. Avaliação da perda de água em Carcaças de frango por Dripping Test e sua relação com carnes PSE (Pale, Soft, Exudative). 2014. 41 f. Monografia (Graduação em Tecnologia de Alimentos) - Universidade Tecnológica Federal do Paraná, Londrina, 2014.

MANCINELLI, A. et al. Mobile Poultry Processing Unit as a Resource for Small Poultry Farms: Planning and Economic Efficiency, Animal
Welfare, Meat Quality and Sanitary Implications. Animals, v. 8, ก. 12, 2018.

BRASIL. Ministério da Agricultura, Pecuária e Abastecimento, Portaria n074, de 7 de maio de 2019 - MAPA. Brasília: DOU, 2019.

NAAS, I. A. et al. Cadeia produtiva da carne de frango no Brasil: um panorama de 10 anos. Revista Brasileira de Ciência Avícola, v. 17, п. 1, p. 87-94, 2015.

NEGRINI, E. et al. Assessment of water absorption levels in frozen chicken carcasses in retail food in the city Campo Grande, MS. Ensaios e Ciência: Ciências Biológicas, Agrárias e da Saúde, v. 11, n. 1, 2007.

NOVELLO, D. et al. Bromatological evaluation and fatty acid profile of meat from broilers fed diets containing fish meal or white oats. Revista Brasileira de Zootecnia, v. 37, n. 9, p. 1660-1668, 2008.

POTENÇA, A. et al. Lipidic profile and tenderness of thigh and drumstick meat of broilers fed diets supplemented with different lipid sources. Revista Brasileira de Zootecnia, v. 39, v. 8, p. 1774-1783, 2010

PAVIM, B. K.; FRANÇA, J. M. The incorporation of water in chicken as economic fraud in Brazil. Revista Higiene Alimentar, v. 25, ก. 202/203, p. 64-68, 2011.

QUEIROZ, A. M.; FREITAS, H. J.; MESSIAS, C. T.; ROSA, B. L.; GONÇALO, E. N. Quantificação de água em carcaças congeladas de frango, comercializadas em Rio Branco, Acre. Enciclopédia Biosfera, v. 14, n. 26, 2017.

QUEIROZ, C.A. U. Influência de carnes PSE(Pale, Soft, Exudative) na absorção e perda de água por gotejamento em carcaças de frango. 2015. 62 f. Dissertação (Mestrado em Tecnologia de Alimentos) - Universidade Tecnológica Federal do Paraná, Londrina, 2015.

R CORE TEAM. R: A language and environment for statistical computing. R Foundation for Statistical Computing, Vienna, Austria, 2013.

SANTANDREU, M. A.; SETANDREU, E. Authenticity of meat products: Tools against fraud. Food Research International, v. 60, p. 19-29, 2014.

SIMAS, V. S.; SANTOS, F. F.; GOUVÊA, R.; AQUINO, M. H. C.; ABREU, D. L. C.; NASCIMENTO, E. R.; PEREIRA, V. L. A. Pré-resfriamento na redução de coliformes em carcaças de frango de corte. Ciência Rural, v. 43, n. 9, p. 1618-1622, 2013. 